\title{
An Approach to the Construction of the Carbon Skeleton of Marine Nor-sesquiterpenes. Total Synthesis of $( \pm)$-Dehalo-Napalilactone
}

\author{
Gaspar Diaz and Fernando Coelho* \\ Departamento de Química Orgânica, Instituto de Química, Universidade Estadual de Campinas \\ CP 6154, 13083-970, Campinas - SP, Brazil
}

\begin{abstract}
Nesse trabalho descrevemos uma abordagem sintética para a preparação de um esqueleto carbônico que tem dois centros quaternários vizinhos, um dos quais apresenta uma unidade espiro $\gamma$-butirolactona. Esse arranjo molecular é encontrado em nor-sesquiterpenos isolados de corais marinhos. A estratégia sintética utilizada se baseou no uso de uma reação de adição 1,4 do dimetilcuprato de lítio sobre a 2-metilcicloexenona, seguida da interceptação do enolato intermediário com brometo de alila, para obter a trans-2-alil-2,3-dimetilcicloexanona com moderada diastereosseletividade. Essa última já tem incorporada em sua estrutura um dos centros quaternários do esqueleto. $\mathrm{O}$ segundo centro quaternário, que porta a unidade espiro $\gamma$-butirolactona, foi preparado através de uma reação de adição de um reagente organolítio, seguido da separação dos isômeros e de etapas de oxidação. Essa estratégia permitiu obter o esqueleto carbônico dos sesquiterpenos e ao mesmo tempo relatar a síntese total de um derivado nor-sesquiterpênico não natural, em 6 etapas com um rendimento global de 16\%, a partir da 2-metilcicloexenona.
\end{abstract}

We disclose herein a synthetic approach for the preparation of an unusual carbon skeleton, which was found in nor-sesquiterpenes isolated from marine corals. The main structural feature of this skeleton is the presence of two contiguous quaternary centers, one of them bears a spiro $\gamma$ butyrolactone moiety. One of the quaternary centers was prepared with moderate stereoselectivity by the conjugate addition of lithium dimethylcuprate to 2-methylcyclohexenone, followed by the trapping of the intermediate enolate with allyl bromide to furnish trans-2-allyl-2,3dimethylcyclohexan-2-one, as a major diastereoisomer. The preparation of the quaternary centers bearing the spiro $\gamma$-butyrolactone moiety was secured by the addition of a suitably functionalized organolithium reagent on trans-2-allyl-2,3-dimetylcyclohexan-2-one, followed by separation of the isomers and two oxidation steps. This strategy has permitted us to report the racemic total synthesis of a non-natural nor-sesquiterpene derivative, in 6 steps and 16\% overall yield, from 2methylcyclohexenone.

Keywords: nor-sesquiterpene, napalilactone, marine natural products, dehalo-napalilactone, pathylactone

\section{Introduction}

Chemical studies of the constituents of terrestrial organisms, particularly those of microorganisms and plants have long been carried out, and the development of this field has been remarkable due to the progress made in chemical instrumentation after World War II. Much work on the constituents of animals such as vitamins, hormones and pheromones has been reported ${ }^{1}$.

However, the search for new compounds from the sea is a relatively recent undertaking. Early studies on the

\footnotetext{
* e-mail: coelho@iqm.unicamp.br
}

chemistry of marine organisms were the domain of organic chemists, most of whom were concerned with the isolation, chemical characterization and phylogenetic variants of specific substances, for example, types of steroids present in diverse marine animals. A symposium held in 1960 on the biochemistry and pharmacology of compounds derived from marine organisms brought researchers together for the first time and gave cohesion and direction to this field ${ }^{2}$.

The living environments of marine organisms differ from that of terrestrial organisms, for example, in the seawater the concentration of halides is very high. Due to these differences the constituents in the marine organisms differ considerably from those of the terrestrial organisms.

The presence of halides in seawater has readily allowed 
marine organisms to incorporate bromine, chlorine, and iodine, in that order, into covalent organic structures. Marine organisms contain abundantly halogenated organic compounds, in particular brominated and chlorinated compounds ${ }^{3}$.

In 1992, P. J. Scheuer et al. ${ }^{4}$ reported the isolation and the structure of a new sesquiterpenoid, Napalilactone (1, Figure 1) from the soft coral Lemnalia africana. This compound was the first example of an halogenated norsesquiterpene to be isolated from a marine organism.

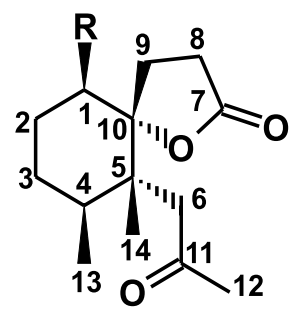

\section{$\mathrm{R}=\mathrm{Cl}$, Napalilactone (1) \\ $\mathrm{R}=\mathrm{H}$, Dehalo-Napalilactone (2) \\ $\mathrm{R}=\mathrm{OH}$, Pathylactone (3)}

Figure 1. Natural and synthetic nor-sesquiterpenes.

This nor-sesquiterpene is biogenetically derivable from an aristolene carbon skeleton. It presents an unusual structure with two contiguous quaternary centers. One of the quaternary centers bears a spiro $\gamma$-butyrolactone unity. Apparently, this halogenated nor-sesquiterpene is part of the coral's chemical defense system ${ }^{4}$.

Recently another nor-sesquiterpene, (pathylactone, $\mathbf{3}$ Figure 1), having the same structural features, has been isolated by J.-Y. Su et al. ${ }^{5}$ from soft coral Paralemnalia thyrsoides.

As part of a current research program directed towards the total synthesis of some marine natural products, we disclose herein our results concerning a strategy for the preparation of the carbon skeleton of these nor-sesquiterpenoids. Our interest was focused on the development of a simple and direct methodology, which allowed us to control the relative configuration of the contiguous quaternary centers. Additional modifications in this methodology should permit us to synthesize $\mathbf{1}$ and $\mathbf{3}$ (Figure 1), in their racemic forms. In this study we describe the synthesis of $( \pm)$-dehalo-napalilactone (2), a non-natural nor-sesquiterpenoid derivative.

\section{Results and Discussion}

From our point of view, the carbon skeleton of the norsesquiterpenes $\mathbf{1}$ and $\mathbf{3}$ could be prepared from the $\alpha$-allyl cyclohexanone $\mathbf{6}$, through the addition of a suitably functionalized organolithium reagent to furnish the diol $\mathbf{5}$ (Scheme 1). The preparation of the spiro- $\gamma$-butyrolactone moiety could be secured by the oxidative cyclization of

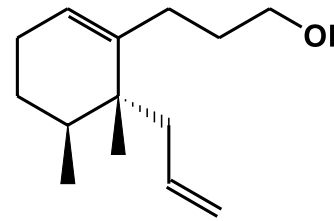

4<smiles>C=CC</smiles>

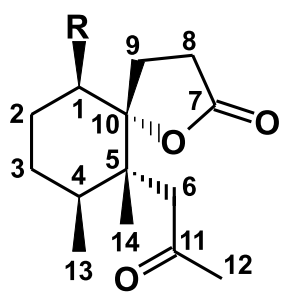

$\mathrm{R}=\mathrm{Cl}$, Napalilactone (1) $\mathrm{R}=\mathrm{OH}$, Pathylactone $(3)$

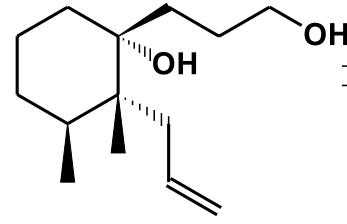

5

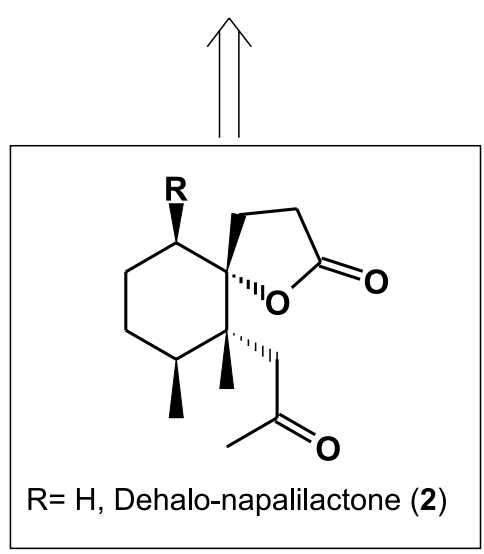<smiles>C=CC[C@]1(C)C(=O)CCC[C@@H]1C</smiles>

6<smiles>C=CCCC</smiles>

7

Scheme 1. Retrosynthetic analysis 
the diol 5, with the correct configuration at C10 (for napalilactone numbering, see Scheme 1). The required ketone $\mathbf{6}$ could be stereoselectively prepared through a conjugate addition of lithium dimethylcuprate to the double bond of 2-methylcyclohexenone (7), followed by the trapping of the copper enolate intermediate with allyl bromide. The control of the relative stereochemistry of the methyl groups at C4 and C5 (napalilactone numeration) should be secured in this step by this simple sequence (Scheme 1).

The ketone 7 could be easily prepared from 2methylcyclohexanol using a standard procedure ${ }^{6}$. Depending on the sucess attained with this strategy, some additional modifications should allow us to synthetize in the future the nor-sesquiterpenes $\mathbf{2}$ and $\mathbf{3}$ in their racemic forms.

\section{Preparation of ketone 6}

The 2-methylcyclohexenone (7) was prepared using a standard procedure ${ }^{6}$ in three steps and $73 \%$ overall yield from commercial 2-methyl-cyclohexanol. To obtain the carbonyl compound $\mathbf{6}$ we decided to take advantage of the greater stereoselectivity and generally greater yields of 1,4addition products obtained using organocopper reagents. Boeckman ${ }^{7}$ has described a methodology based on a stereo- and regioselective double alkylation of $\alpha, \beta$-unsaturated ketones. The 1,4-addition of lithium dimethylcuprate to 2methylcyclohexenone ${ }^{7}$, followed by the regioselective alkylation of the copper enolate intermediate with allyl bromide, gave the allyl ketone $\mathbf{6 a} / \mathbf{b}$ as a diastereoisomeric mixture (GC analysis, cis:trans 20:80) (Scheme 2).

The selectivity obtained in the preparation of ketone 6 can be rationalised by the conformation of the cuprate enolate intermediates A and B (Figure 2). Due to a $A^{1(2)}$ strain ${ }^{8,9}$ conformation $\mathrm{B}$ is preferred and the electrophilic attack takes place from the less hindered face of the double bond, thus leading preferentially to the methyl groups in a cis relationship (Figure 2).

The diastereoisomeric mixture was readily separated by column chromatography on silica gel to furnish ketone trans-6b, as a pure isomer in $62 \%$ yield. Boeckman reported a diastereoselection ratio of 10:90 (cis:trans). Unfortunately others ${ }^{10}$ as well as ourselves were unable to reproduce this result.

The relative stereochemistry of the new stereogenic centers of $\mathbf{6} \mathbf{b}$ was confirmed by comparison with the data available in the literature ${ }^{11}$. We have tried to confirm the stereochemical assignments by ${ }^{1} \mathrm{H}$ NMR spectra, by the irradiation of the signals of the methyl groups at C13 and C14. Unfortunately the results were not conclusive, mainly

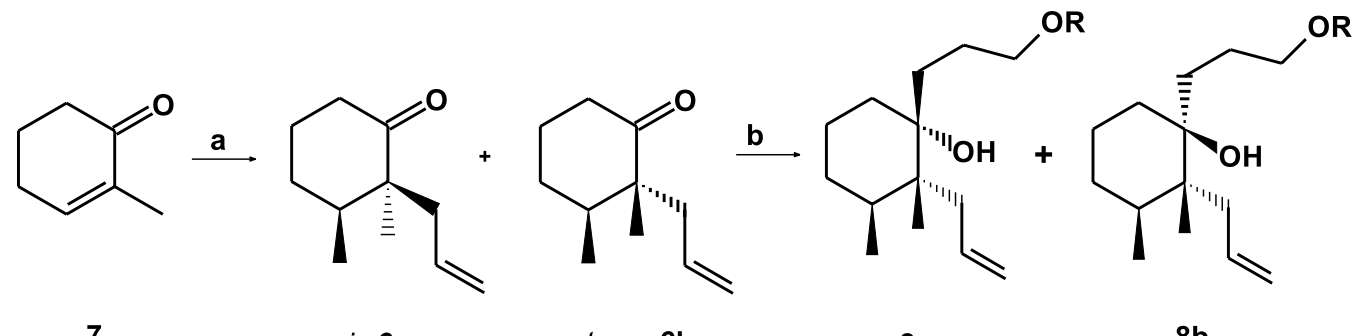

7 cis-6a trans-6b $8 a$ $8 b$

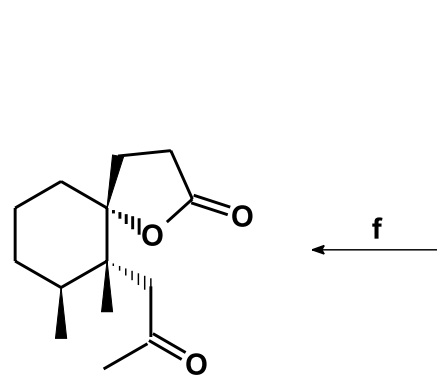

(+/-)-Dehalo-napalilactone (2)

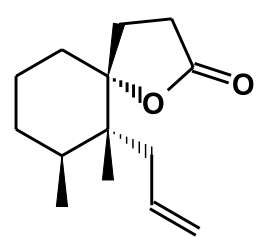

10

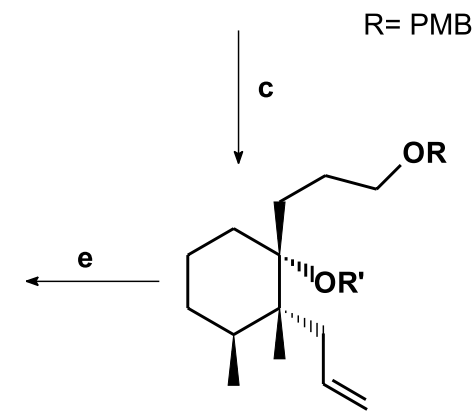

9, $\mathrm{R}=\mathrm{PMB} ; \mathrm{R}^{\prime}=\mathrm{TMS}$ 5, R, R'= H

Reagents and conditions: a. i) $\left(\mathrm{CH}_{3}\right)_{2} \mathrm{CuLi}$, ether, $0^{\circ} \mathrm{C}$; ii) DME, allyl bromide, r.t., 3h, (1:4); iii) chromatographic separation, $75 \%$. b. i) t-BuLi, iodide $11,-23^{\circ} \mathrm{C} \rightarrow 0^{\circ} \mathrm{C}$, ether, $1 \mathrm{~h}, 68 \%$; ii) ketone $6 \mathbf{b}, 0^{\circ} \mathrm{C}, 1 \mathrm{~h}, 68 \%$ (92\% based on recovered starting-material); iii) chromatographic separation c. TMSOTf, $\mathrm{CH}_{2} \mathrm{Cl}_{2}$, DIPEA, $-78^{\circ} \mathrm{C}, 6 \mathrm{~h}$, quantitative; d) DDQ, $\mathrm{CH}_{2} \mathrm{Cl}_{2} / \mathrm{H}_{2} \mathrm{O}(18: 1), 2.5 \mathrm{~h}$ then $(n \text {-Bu })_{4} \mathrm{~N}^{+} \mathrm{F}^{-}, 1 \mathrm{~h}, 92 \%$; e. TPAP, NMO, $4 \AA$ molecular sieves, $\mathrm{CH}_{2} \mathrm{Cl}_{2}: \mathrm{CH}_{3} \mathrm{CN}$ $10 \%, 1 \mathrm{~h}, 80 \%$; f. $\mathrm{PdCl}_{2}, \mathrm{Cu}(\mathrm{OAc})_{2}$, N,N-dimetylacetamide/water $(7: 1), \mathrm{O}_{2}, 3$ days, r.t., $60 \%$. 


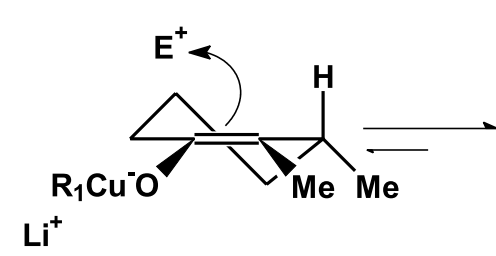

A

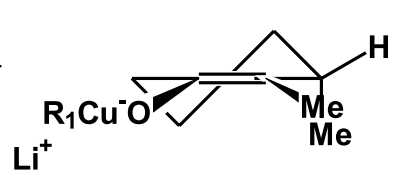

B

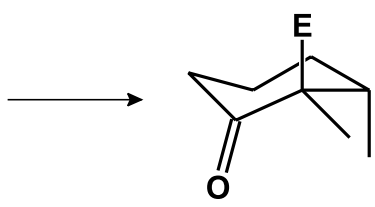

ketone $\mathbf{6 b}$

Figure 2. Rationalisation for the diasterereoselectivity obtained in the preparation of $\mathbf{6}$.

due to saturation of the signal of the methyl group at $\mathrm{C} 13$ when the signal of the $\mathrm{C} 14$ methyl group was irradiated and vice-versa.

\section{Preparation of the spiro $\gamma$-butyrolactone unity}

To prepare the spiro $\gamma$-butyrolactone moiety at $\mathrm{C} 10$, it was necessary to add a suitably functionalized $\mathrm{C} 3$ residue to the ketone $\mathbf{6 b}$. In our view the most direct way to do this was through the 1,2-addition of an organometallic reagent. The $\mathrm{C} 3$ residue was readily obtained from 1,3-propanodiol by using the methodology recently described by Forsyth ${ }^{12}$ and $\mathrm{Chen}^{13}$. Treatment of 1,3-propanodiol with sodium hydride in THF at $0^{\circ} \mathrm{C}$, followed by the addition of $p$ methoxy-benzyl chloride furnished PMB-ether alcohol intermediate, in $84 \%$ yield. The mesylation of the alcohol, followed by substitution with NaI, provided the iodide 11, in $98 \%$ yield for the two steps (see experimental section).

The ketone trans-6b was treated at $-23^{\circ} \mathrm{C}$ with the organolithium compound derived from the iodide $\mathbf{1 1}$ (generated by in situ treatment with an ethereal solution of $t$-butyllithium) to furnish the tertiary alcohol $\mathbf{8}$, as a mixture of diastereoisomers (ratio $\mathbf{8 a} / \mathbf{8 b} 1: 1$ ) (Scheme 2).

Unfortunately no stereoselectivity was observed in this step, however the diastereomeric alcohols $\mathbf{8 a} / \mathbf{8 b}$ were easily separated by flash column chromatography.

In order to proceed with our planned synthetic strategy it was necessary to determine the relative stereochemistry of the new stereogenic center. All attempts to do this by ${ }^{1} \mathrm{H}$ NMR (nOe) failed. In fact the results obtained with the nOe experiments were not conclusive. The problem of the relative stereochemistry of the diastereoisomers $\mathbf{8 a} / \mathbf{8 b}$ was solved by the ozonolysis of the separated diastereoisomers at $-78^{\circ} \mathrm{C}$ which after treatment with dimethyl sulfide gave the hemiacetal 12 and the aldehyde 13 (Scheme 4). From our point of view the formation of the hemiacetal 12 from the alcohol 8a is an unambiguous proof that the hydroxyl group and the aldehyde are syn. These results confirmed that the hydroxyl group of alcohol $\mathbf{8 a}$ was $\alpha$ oriented and $\beta$ oriented on alcohol $\mathbf{8 b}$ (Scheme 3).

To prepare the spiro- $\gamma$-butyrolactone it was necessary to remove the $p$-methoxybenzyl group. All attempts to cleave this protection group using 2,3-dichloro-5,6dicyano-benzoquinone (DDQ) in the presence of the free tertiary hydroxyl group lead to a mixture, where it was impossible to detect the expected product. To avoid this problem the tertiary alcohol $\mathbf{8 a}$ was first transformed to the trimethylsilyl ether 9 (Scheme 2). Then the silylether 9 was treated with DDQ in dichloromethane/water, followed by the addition of tetrabutylammonium fluoride $\left(n-\mathrm{Bu}_{4} \mathrm{NF}\right)$ to remove the silyl group. This simple protocol provided the diol 5 in $92 \%$ yield for the two steps (Scheme 2).

The diol 5 was readily transformed into the spiro- $\gamma$ -
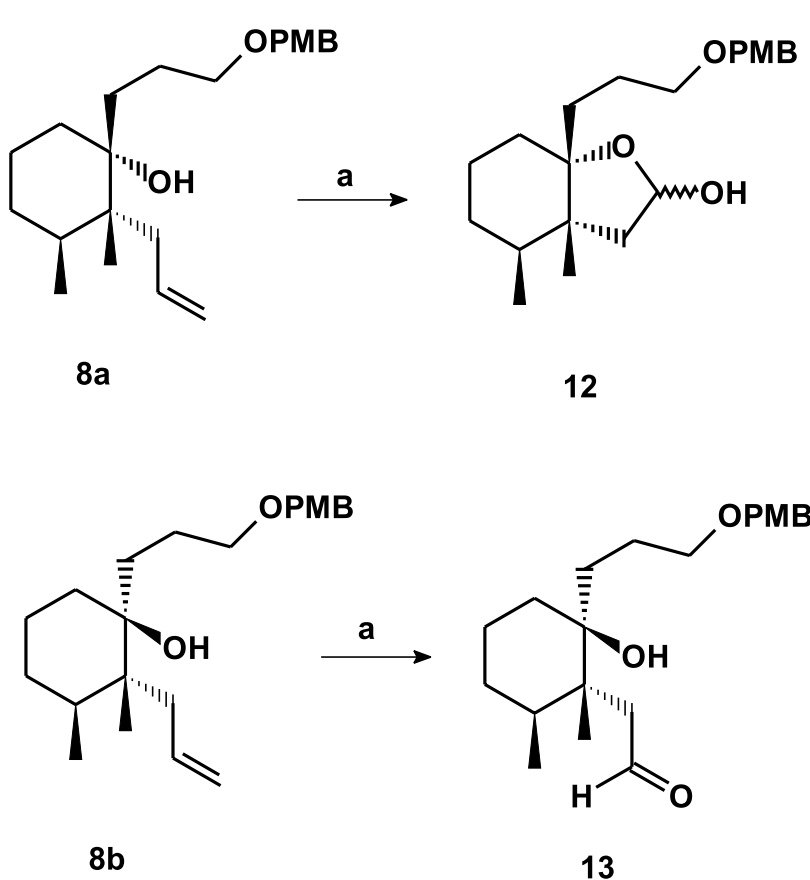

Reagents and conditions: a. i) $\mathrm{O}_{3}, \mathrm{CH}_{2} \mathrm{Cl}_{2},-78^{\circ} \mathrm{C}, 30$ min.; ii) $\left(\mathrm{CH}_{3}\right)_{2} \mathrm{~S}$, t.a., $12 \mathrm{~h}, 50 \%$.

Scheme 3. Chemical proof for the stereochemistry of $\mathbf{8 a} / \mathbf{8 b}$ 
butyrolactone $\mathbf{1 0}$ by treatment with tetraisopropylammoniumperruthenate (TPAP) in the presence of

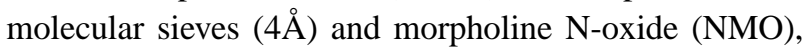
in accordance with the methodology described by Mehta and Karra ${ }^{14}$. Under these conditions the primary hydroxyl group was oxidized to an aldehyde which was transformed in situ into a hemiacetal intermediate ${ }^{14}$, which was oxidized to the lactone $\mathbf{1 0}$ (Scheme 2).

At this stage we had incorporated almost all the functionality of the nor-sesquiterpene structure with the suitable relative configuration. To complete our reaction sequence the product $\mathbf{1 0}$ was submitted to a modified Wacker reaction ${ }^{15}$. The lactone $\mathbf{1 0}$ was treated with $\mathrm{PdCl}_{2}$ and $\mathrm{Cu}(\mathrm{OAc})_{2}$ in a mixture of $\mathrm{N}, \mathrm{N}$-dimethylacetamide and $\mathrm{H}_{2} \mathrm{O}(7: 1)$ to furnish the ( \pm )-dehalo-napalilactone (2), as a white solid (Scheme 2).

\section{Experimental}

\section{General}

The ${ }^{1} \mathrm{H}$ and ${ }^{13} \mathrm{C}$ NMR spectra were recorded on a Varian GEMINI BB-300 at 300MHz and $75.1 \mathrm{MHz}$ respectively. The ${ }^{1} \mathrm{H}$ spectra were also recorded in an AW-80 Bruker at $80 \mathrm{MHz}$ and Inova 500MHz. The mass spectra were recorded using a CG/MS HP model 5988A and an Autospec-Micromass - EBE - High Resolution. The melting points were measured in open capilary tubes using an Electrothermal apparatus model 9100, and are uncorrected. Purification and separations by column chromatography were performed on silica gel, using normal or flash chromatography. Ether and THF were distilled from benzophenone ketyl under nitrogen. Dichloromethane was distilled from $\mathrm{CaH}_{2}$. TLC visualization was achieved by spraying with $5 \%$ ethanolic phosphomolybdic acid and heating. All the organolithium reagents were purchased from Aldrich Chemical Company.

\section{Synthesis of (土)-2-allyl-2,3-dimethylcyclohexan-1-one (6a/6b)}

To a suspension of CuI (7.79 $\mathrm{g}, 41.0 \mathrm{mmol})$ in anhydrous ether $\left(90 \mathrm{~cm}^{3}\right)$ was added an ethereal solution of methyllithium $\left(65 \mathrm{~cm}^{3}, 82.0 \mathrm{mmol}, \mathrm{ca} .1 .25 \mathrm{~mol} \mathrm{dm}\right.$ ), at $0^{\circ} \mathrm{C}$, under an inert atmosphere of $\mathrm{N}_{2}$. After $15 \mathrm{~min}$ at $0^{\circ} \mathrm{C}$, a solution of $7(3.0 \mathrm{~g}, 27.27 \mathrm{mmol})$ in anhydrous ether $\left(30 \mathrm{~cm}^{3}\right)$ was added to the ethereal solution of lithium dimethylcuprate. After $60 \mathrm{~min}$, at $0^{\circ} \mathrm{C}$ the solvent was removed under reduced pressure (CAUTION: Avoid drying the reaction media completely as it is well known in the literature that some dry $\mathrm{RCu}$ compounds can explode $)^{16}$. To the resulting yellow wet solid was added DME $\left(65 \mathrm{~cm}^{3}\right)$, under a $\mathrm{N}_{2}$ atmosphere giving rise to a greenish black solution, to which allyl bromide $\left(19.0 \mathrm{~cm}^{3}\right.$, $218 \mathrm{mmol}$ ) was added, at $0{ }^{\circ} \mathrm{C}$. The final solution was stirred for $15 \mathrm{~min}$. After that, the reaction was quenched with a saturated solution of $\mathrm{NaHCO}_{3}\left(200 \mathrm{~cm}^{3}\right)$, followed by the addition of a $10 \%$ solution of $\mathrm{NH}_{4} \mathrm{OH}\left(45 \mathrm{~cm}^{3}\right)$. The blue aqueous phase was extracted with pentane $\left(3 \times 200 \mathrm{~cm}^{3}\right)$. The combined organic layers were washed with a $10 \%$ solution of $\mathrm{NH}_{4} \mathrm{OH}\left(50 \mathrm{~cm}^{3}\right)$ and distilled water $\left(100 \mathrm{~cm}^{3}\right)$. The organic phase was dried over anhydrous $\mathrm{MgSO}_{4}$ and the solvent was removed under reduced pressure. The oily residue was purified by flash column chromatography (silica gel 230-400 mesh, eluting with hexane-ethyl acetate 99:1 v/v) to furnish ketone cis-6a $(0.68 \mathrm{~g}, 15 \%)$ and ketone trans-6b $(2.74 \mathrm{~g}, 62 \%)$, as colorless oils.

Ketone cis-6a: IR $v_{\max } / \mathrm{cm}^{-1} 3073,2960,2924,2871$, 2353, 1706 (CO), 1634, 1456, 1385, 1319, 1141, 1034, 909, 808 (film); ${ }^{1} \mathrm{H}$ NMR (500 MHz, $\left.\mathrm{CDCl}_{3}\right) \delta 5.61-5.54$ $(\mathrm{m}, 1 \mathrm{H}), 5.07-5.0(\mathrm{~m}, 2 \mathrm{H}), 2.49(\mathrm{dd}, J 14.0$ and $7.6 \mathrm{~Hz}$, $1 \mathrm{H}), 2.42-2.38(\mathrm{~m}, 1 \mathrm{H}), 2.34-2.30(\mathrm{~m}, 1 \mathrm{H}), 2.11(1 \mathrm{H}, \mathrm{dd}$, $J 14.0$ and $7.0 \mathrm{~Hz}), 2.03-1.97(\mathrm{~m}, 1 \mathrm{H}), 1.75-1.64(\mathrm{~m}, 4 \mathrm{H})$, 1.09 (s, 3H), 0.98 (d, J $6.6 \mathrm{~Hz}, 3 \mathrm{H})$.

Ketone trans-6b: IR $v_{\text {max }} / \mathrm{cm}^{-1} 3073,2960,2924,2871$, 2353, 1706 (CO), 1634, 1456, 1385, 1319, 1141, 1034, 909, 808 (film); ${ }^{1} \mathrm{H} \mathrm{NMR}\left(\mathrm{CDCl}_{3}, 300 \mathrm{MHz}\right) \delta$ 5.80-5.66 (m,1H), 5.07-5.00 (m, 2H), 2.52 (dd, J 14.0 and $8.4 \mathrm{~Hz}$, $1 \mathrm{H}), 2.47-2.28(\mathrm{~m}, 2 \mathrm{H}), 2.17(\mathrm{dd}, J 14.0$ and $8.4 \mathrm{~Hz}), 2.0-$ 1.87 (m, 2H), 1.85-1.75 (m, 1H), 1.74-1.65 (m ,1H), 1.64$1.50(\mathrm{~m}, 1 \mathrm{H}), 1.0(\mathrm{~s}, 3 \mathrm{H}), 0.91(\mathrm{~d}, J 7.0 \mathrm{~Hz}, 3 \mathrm{H}) ;{ }^{13} \mathrm{C} \mathrm{NMR}$ $\left(75.4 \mathrm{MHz}, \mathrm{CDCl}_{3}\right) \delta 216.2,135.4,117.6,52.3,40.8,38.5$, $38.4,29.1,24.3,18.9,15.2$.

\section{Synthesis of 1-[(4-methoxybenzyl)oxy)]-3-propyl iodide(11)}

To a suspension of $\mathrm{NaH}(1.6 \mathrm{~g}, 39.6 \mathrm{mmol}, 60 \%$ in mineral oil, washed with dry hexane before use) in dry THF $\left(220 \mathrm{~cm}^{3}\right)$, at $0^{\circ} \mathrm{C}$, under argon, was added 1,3propanediol (1.3 g, $33 \mathrm{mmol})$. The resulting mixture was warmed to room temperature and stirred for $1 \mathrm{~h}$. After this time, the mixture was cooled to $0^{\circ} \mathrm{C}$ and to the cooled suspension was added tetrabutylammonium iodide $(2.44$ $\mathrm{g}, 6.61 \mathrm{mmol}$ ) and $p$-methoxybenzylchloride (PMBCl, 5.4 $\left.\mathrm{cm}^{3}, 39.6 \mathrm{mmol}\right)$. The reaction mixture was warmed again to room temperature and stirred for $24 \mathrm{~h}$. The reaction mixture was subsequently hydrolysed by the addition of a saturated solution of $\mathrm{NH}_{4} \mathrm{Cl}\left(100 \mathrm{~cm}^{3}\right)$ and extracted with ethyl ether $\left(2 \times 250 \mathrm{~cm}^{3}\right)$. The organic phase was washed with a saturated solution of $\mathrm{NH}_{4} \mathrm{Cl}\left(75 \mathrm{~cm}^{3}\right)$, distilled water $\left(2 \times 75 \mathrm{~cm}^{3}\right)$, brine $\left(2 \times 75 \mathrm{~cm}^{3}\right)$ and dried over anhydrous $\mathrm{Na}_{2} \mathrm{SO}_{4}$. After the evaporation of the solvent under reduced pressure, the residue was purified by column chromatography to furnish 1-[(4-methoxybenzyl)oxy)]-3-propanol 
(5.43 $\mathrm{g}, 84 \%)$, as a colorless oil.

IR $v_{\text {max }} / \mathrm{cm}^{-1} 3412,3007,2948,2871,2062,1997,1896$, 1622, 1468, 1373, 1313, 1260, 1177, 1087, 1034, 832 (film); $\left.{ }^{1} \mathrm{H} \mathrm{RMN} \mathrm{(300} \mathrm{MHz,} \mathrm{CDCl}_{3}\right) \delta 7.25(\mathrm{~d}, J 8.8 \mathrm{~Hz}$, $2 \mathrm{H}), 6.87$ (d, J 8.8 Hz, 2H), 4.44 (s, 2H), 3.79 (s, 3H), 3.75 $(\mathrm{t}, J 6.0 \mathrm{~Hz}, 2 \mathrm{H}), 3.62(\mathrm{t}, J 6.0 \mathrm{~Hz}), 2.65-2.25(\mathrm{bs}, 1 \mathrm{H}$, echangeable with $\mathrm{D}_{2} \mathrm{O}$ ), 1.84 (quint, $J 6.0 \mathrm{~Hz}, 2 \mathrm{H}$ ); ${ }^{13} \mathrm{C}$ $\mathrm{RMN}\left(75.4 \mathrm{MHz}, \mathrm{CDCl}_{3}\right): \delta 159.2,130.1,129.2,113.8$, 72.8, 68.9, 61.7, 55.2, 32.0.

To a solution of alcohol obtained above $(3.0 \mathrm{~g}, 13.3$ $\mathrm{mmol})$ in dry dichloromethane $\left(105 \mathrm{~cm}^{3}\right)$ was slowly added, at $0{ }^{\circ} \mathrm{C}$, triethylamine $\left(2.3 \mathrm{~cm}^{3}, 16.8 \mathrm{mmol}\right)$ and mesyl chloride $\left(1.55 \mathrm{~cm}^{3}, 20 \mathrm{mmol}\right)$. To the resulting mixture was added a solution of 4-dimetylaminopyridine (DMAP) in dry dichloromethane $\left(5 \mathrm{~cm}^{3}\right)$. The final solution was stirred for $2 \mathrm{~h}$ at room temperature. After which time cold water $\left(100 \mathrm{~cm}^{3}\right)$ was added to the reaction and the mixture was extracted with ethyl acetate $\left(2 \times 100 \mathrm{~cm}^{3}\right)$. The combined organic layers were washed with a solution of $\mathrm{HCl}(0.1$ $\left.\mathrm{mol} \mathrm{dm} 3,50 \mathrm{~cm}^{3}\right), \mathrm{NaHCO}_{3} 5 \%\left(2 \times 50 \mathrm{~cm}^{3}\right)$ and brine $(50$ $\mathrm{cm}^{3}$ ). The organic layer was dried over anhydrous $\mathrm{Na}_{2} \mathrm{SO}_{4}$ and the solvent evaporated under reduced pressure. The residue (4.18g, quantitative yield) was sufficiently pure (by t.l.c) to be used in the next step without purification.

To a solution of the mesylate $(4.10 \mathrm{~g}, 15.0 \mathrm{mmol})$ in acetone $\left(156 \mathrm{~cm}^{3}\right)$ was added sodium iodide $(11.25 \mathrm{~g}, 75$ $\mathrm{mmol})$. The resulting mixture was refluxed, under argon, for $6 \mathrm{~h}$. After cooling to room temperature distilled water $\left(260 \mathrm{~cm}^{3}\right)$ was added and the mixture was extracted with ethyl ether $\left(2 \times 200 \mathrm{~cm}^{3}\right)$. The combined organic layers were washed with brine $\left(2 \times 130 \mathrm{~cm}^{3}\right)$. The aqueous phases were combined and extracted with more ethyl ether $(2 \mathrm{x}$ $200 \mathrm{~cm}^{3}$ ). The organic layers were combined and dried over anhydrous $\mathrm{Na}_{2} \mathrm{SO}_{4}$. After evaporation of the solvent, the residue was purified by column chromatography to furnish iodide 11 (4.5 g, 98\%).

IR $v_{\max } / \mathrm{cm}^{-1} 3001,2936,2894,2865,1616,1581,1521$, 1462, 1373, 1307, 1248, 1177, 1093, 1034, 826 (film); ${ }^{1} \mathrm{H}$ NMR (300 MHz, $\left.\mathrm{CDCl}_{3}\right) \delta 7.26(\mathrm{~d}, J 8.8 \mathrm{~Hz}), 6.88(\mathrm{~d}, J$ $8.8 \mathrm{~Hz}, 2 \mathrm{H}), 4.44(\mathrm{~s}, 2 \mathrm{H}), 3.80(\mathrm{~s}, 3 \mathrm{H}), 3.51(\mathrm{t}, J 6.0 \mathrm{~Hz}$, $2 \mathrm{H}), 3.29$ (t, J 6.7 Hz, 2H), 2.07 (quint, $J 6.0 \mathrm{~Hz}, 2 \mathrm{H}) ;{ }^{13} \mathrm{C}$ NMR $\left(75.4 \mathrm{MHz}, \mathrm{CDCl}_{3}\right) \delta 159.2,130.3,129.3,113.8$, $72.7,69.3,55.2,33.5,3.5$.

\section{Synthesis of (土)-2-allyl-1-[3-(4-methoxybenzyloxy)propyl]- 2,3-dimethylcyclohexan-1-ol (8a/8b)}

To a stirred solution of the iodide $11(0.91 \mathrm{~g}, 3.0 \mathrm{mmol})$ in anhydrous ether $\left(20 \mathrm{~cm}^{3}\right)$ was added $t$-butyllithium $(4.48$ $\mathrm{cm}^{3}, 3.0 \mathrm{mmol}$ ) at $-23^{\circ} \mathrm{C}$, under $\mathrm{N}_{2}$ atmosphere. The resulting solution was stirred for $20 \mathrm{~min}$ at $-23^{\circ} \mathrm{C}$ and allowed to warm to $0^{\circ} \mathrm{C}$, before a solution of the ketone $6 \mathbf{b}(0.33 \mathrm{~g}, 2.0 \mathrm{mmol})$ in anhydrous ether $\left(20 \mathrm{~cm}^{3}\right)$ was slowly added (via canula). The final solution was stirred for $60 \mathrm{~min}$ at $0^{\circ} \mathrm{C}$. The reaction medium was quenched with a saturated solution of $\mathrm{NH}_{4} \mathrm{Cl}$ $\left(13 \mathrm{~cm}^{3}\right)$ and extracted with ether $\left(2 \times 65 \mathrm{~cm}^{3}\right)$. The combined organic layers were washed with a saturated solution of $\mathrm{NH}_{4} \mathrm{Cl}\left(40 \mathrm{~cm}^{3}\right)$, distilled water $\left(2 \times 40 \mathrm{~cm}^{3}\right)$ and finally brine $\left(2 \times 40 \mathrm{~cm}^{3}\right)$. The combined aqueous layers were extracted twice with ether $\left(65 \mathrm{~cm}^{3}\right)$. The combined organic layers were dried over $\mathrm{MgSO}_{4}$, and the solvent was removed under reduced pressure. The mixture of diastereoisomeric alcohols (CG 50:50 ratio) was easily separated by flash column chromatography (silica gel 230-400 mesh, eluting with hexane-ethyl acetate 99:1 and 95:5 v/v) to furnish the alcohol 8a $(0.24 \mathrm{~g}, 34 \%$ or $46 \%$ based on the recovered starting material) and the alcohol $\mathbf{8 b}(0.24 \mathrm{~g}, 34 \%$ or $46 \%$ based on the recovered starting material).

Alcohol 8a: IR $v_{\max } / \mathrm{cm}^{-1} 3459,3079,2936,2871,1616$, 1515, 1474, 1373, 1313, 1248, 1183, 1099, 1046, 915, 826, 749 (film); ${ }^{1} \mathrm{H}$ NMR $\left(300 \mathrm{MHz}, \mathrm{CDCl}_{3}\right) \delta 7.26(\mathrm{~d}, J 8.8$ $\mathrm{Hz}, 2 \mathrm{H}), 6.88(\mathrm{~d}, J 8.8 \mathrm{~Hz}, 2 \mathrm{H}), 6.10(\mathrm{~m}, 1 \mathrm{H}), 5, .07(\mathrm{~m}$, $1 \mathrm{H}), 5.02(\mathrm{~m}, 1 \mathrm{H}), 4.44(\mathrm{~s}, 2 \mathrm{H}), 3.80(\mathrm{~s}, 3 \mathrm{H}), 3.49-3.45$ (m, 2H), 2.24-2.11 (m, 2H), 2.0-1.92 (m, 1H), 1.81-1.67 $(\mathrm{m}, 2 \mathrm{H}), 1.64-1.43(\mathrm{~m}, 2 \mathrm{H}), 1.39-1.21(\mathrm{~m}, 2 \mathrm{H}), 1.0(\mathrm{~s}, 3 \mathrm{H})$, 0,84 (d, J 6.6 Hz,); $\left.{ }^{13} \mathrm{C} \mathrm{NMR} \mathrm{(75.4} \mathrm{MHz,} \mathrm{CDCl}_{3}\right) \delta 159.1$, 138.3, 130.7, 129.1, 116.5, 113.7, 77.3, 72.3, 70.7, 55.2, 45.1, 41.5, 37.5, 30.8, 30.3, 30.1, 23.3, 22.0, 16.6, 13.0; MS (70eV, m/z): $346(\mathrm{M}+, 3 \%), 287(2 \%), 207(6 \%), 121$ (100\%), $77(7 \%)$; HRMS (M+) Calc. for $\mathrm{C}_{22} \mathrm{H}_{34} \mathrm{O}_{3}$ 346.25080. Found: 346.25072.

Alcohol $8 \boldsymbol{b}$ : IR $v_{\max } / \mathrm{cm}^{-1} 3459,3079,2954,2936,2859$, 1616, 1527, 1468, 1367, 1307, 1248, 1183, 1111, 1046, 927, 826 (film); ${ }^{1} \mathrm{H}$ NMR (300 MHz, $\left.\mathrm{CDCl}_{3}\right) \delta 7.26$ (d, $J$ $8.8 \mathrm{~Hz}, 2 \mathrm{H}), 6.87$ (d, J $8.8 \mathrm{~Hz}, 2 \mathrm{H}), 6.14(\mathrm{~m}, 1 \mathrm{H}), 5.08$ $(\mathrm{m}, 1 \mathrm{H}), 5.01(\mathrm{~m}, 1 \mathrm{H}), 4.43(\mathrm{~s}, 2 \mathrm{H}), 3.80(\mathrm{~s}, 3 \mathrm{H}), 3.50-3.40$ $(\mathrm{m}, 2 \mathrm{H}), 2.37(\mathrm{dd}, J 10.0$ and $9.5 \mathrm{~Hz}, 1 \mathrm{H}), 2.25-2.13(\mathrm{~m}$, 2H), 1.95 (brs, exchangeable with $\left.\mathrm{D}_{2} \mathrm{O}, 1 \mathrm{H}\right), 1.79-1.22(\mathrm{~m}$, $10 \mathrm{H}), 0.85$ (d, J 6.6 Hz, 3H), 0.78 (s, 3H); ${ }^{13} \mathrm{C}$ NMR $(75.4$ $\left.\mathrm{MHz}, \mathrm{CDCl}_{3}\right) \delta 159.0,138.8,130.6,129.2,116.2,113.7$, 77.4, 72.3, 70.8, 55.2, 44.7, 39.9, 33.3, 31.8, 31.5, 30.2, 23.4, 21.1, 17.3, 16.1; MS (70eV, $\mathrm{m} / \mathrm{z}): 346(\mathrm{M}+, 3 \%)$, 287 (2\%), 207 (6\%), 121 (100\%), 77 (7\%); HRMS (M+) Calc. for $\mathrm{C}_{22} \mathrm{H}_{34} \mathrm{O}_{3} 346.25080$; Found: 346.25072.

Synthesis of (土)-2-allyl-1-[3-(4-methoxybenzyloxy)propyl]2,3-dimethylcyclohexan-1-trimethylsilyloxyether (9)

To a stirred mixture of alcohol 8a $(0.06 \mathrm{~g}, 0.173 \mathrm{mmol})$ in anhydrous $\mathrm{CH}_{2} \mathrm{Cl}_{2}\left(0,6 \mathrm{~cm}^{3}\right)$ and DIPEA $\left(0.3 \mathrm{~cm}^{3}, 1.73\right.$ $\mathrm{mmol})$ at $-78{ }^{\circ} \mathrm{C}$ was slowly added TMSOTf $\left(0.30 \mathrm{~cm}^{3}\right.$, $1.73 \mathrm{mmol})$. After $4 \mathrm{~h}$ the cooling bath was removed and 
the reaction medium was warmed to room temperature, stirring was maintained for a further $4 \mathrm{~h}$. After that, methanol $\left(6 \mathrm{~cm}^{3}\right)$ was added and the solvents were removed under reduced pressure. The residue was purified by flash column chromatography (silica gel 230-400 mesh, eluting with hexane-ethyl acetate 99:1) to furnish 9 (0.072 g, quantitative yield) as a colorless oil.

IR $v_{\max } / \mathrm{cm}^{-1} 3073,2960,2859,1616,1527,1468,1248$, 1064, 1040, 838 (film); ${ }^{1} \mathrm{H} \mathrm{NMR}\left(300 \mathrm{MHz}, \mathrm{CDCl}_{3}\right) \delta 7.24$ $(\mathrm{d}, J 8.8 \mathrm{~Hz}, 2 \mathrm{H}), 6.84(\mathrm{~d}, J 8.8 \mathrm{~Hz}, 2 \mathrm{H}), 6.07-5.93(\mathrm{~m}, 1 \mathrm{H})$, 4.87-4.78 (m, 2H), $4.41(s, 2 \mathrm{H}), 3.77(\mathrm{~s}, 3 \mathrm{H}), 3.48-3.34(\mathrm{~m}$, $2 \mathrm{H}), 2.12-2.01(\mathrm{~m}, 2 \mathrm{H}), 1.84-1.78(\mathrm{~m}, 1 \mathrm{H}), 1.62-1.45(\mathrm{~m}$, $2 \mathrm{H}), 1.36-1.13(\mathrm{~m}, 2 \mathrm{H}), 0.81(\mathrm{~s}, 3 \mathrm{H}), 0.8(\mathrm{~d}, J 6.2 \mathrm{~Hz}, 3 \mathrm{H})$, $0.05(\mathrm{~s}, 9 \mathrm{H}) ;{ }^{13} \mathrm{C}$ NMR $\left(75.4 \mathrm{MHz}, \mathrm{CDCl}_{3}\right) \delta 159.0,138.9$, 130.8, 129.2, 113.8, 113.7, 81.7, 72.3, 70.9, 55.2, 45.3, 41.5, $37.8,32.2,30.6,30.5,24.0,22.7,17.1,14.1,3.1$.

Synthesis of ( \pm )-2-allyl-1-(3-hydroxypropyl)-2,3dimethylcyclohexan-1-ol (5)

To a solution of PMB-ether $9(0.071 \mathrm{~g}, 0.17 \mathrm{mmol})$ in a mixture of $\mathrm{CH}_{2} \mathrm{Cl}_{2}\left(4 \mathrm{~cm}^{3}\right)$ and distilled water $\left(0.22 \mathrm{~cm}^{3}\right)$ was added 2,3-dichloro-5,6-dicyano-benzoquinone (DDQ). The resulting mixture was stirring for $2.5 \mathrm{~h}$ at room temperature, after that tetrabutylammonium fluoride $\left(n-\mathrm{Bu}_{4} \mathrm{NF}, 0.045 \mathrm{~g} 0.17\right.$ mmol) was added to the reaction media. The solution was stirred for a further $1 \mathrm{~h}$ at room temperature. The reaction was then quenched with a saturated solution of $\mathrm{NaHCO}_{3}\left(3 \mathrm{~cm}^{3}\right)$ and extracted with $\mathrm{Et}_{2} \mathrm{O}\left(3 \times 10 \mathrm{~cm}^{3}\right)$. The combined organic phases were washed with a saturated solution of $\mathrm{NaHCO}_{3}(10$ $\left.\mathrm{cm}^{3}\right)$, brine $\left(10 \mathrm{~cm}^{3}\right)$ and dried over anhydrous $\mathrm{MgSO}_{4}$. After the evaporation of the solvent under reduced pressure the residue was purified by flash chromatography (eluting with hexane:ethyl acetate 70:30), to furnish the diol 5 (0.038 g, quantitative yield), as a colorless oil.

$\operatorname{IR}\left(v_{\max } / \mathrm{cm}^{-1}\right)$ 3500-3500, 2960, 2859, 1616, 1527, 1468; ${ }^{1} \mathrm{H}$ NMR $\left(300 \mathrm{MHz}, \mathrm{CDCl}_{3}\right) \delta$ 6.17-6.05 (m, 1H), 5.15-5.06 (m, 2H), 3.48 (t, J $6.6 \mathrm{~Hz}, 2 \mathrm{H}), 2.45$ (brs, $1 \mathrm{H}$, exchangeable with $\left.\mathrm{D}_{2} \mathrm{O}\right), 2.28-2.14(\mathrm{~m}, 2 \mathrm{H}), 2.05-1.96(\mathrm{~m}$, $1 \mathrm{H}), 1.63-1.5(\mathrm{~m}, 2 \mathrm{H}), 1,41-1,33(\mathrm{~m}, 2 \mathrm{H}), 1.31-1.22(\mathrm{~m}$, $2 \mathrm{H}), 1.01(\mathrm{~s}, 3 \mathrm{H}), 0.86(\mathrm{~d}, J 6.6 \mathrm{~Hz}, 3 \mathrm{H}) ;{ }^{13} \mathrm{C}$ NMR $(75.4$ $\left.\mathrm{MHz}, \mathrm{CDCl}_{3}\right) \delta 138.2,116.8,77.7,61.7,45.1,41.4,37.6$, 31.5, 30.8, 26.3, 22.0, 19.2, 16.6, 13.0; $\mathrm{MS}(70 \mathrm{eV}, \mathrm{m} / \mathrm{z})$ : $226(\mathrm{M}+, 6 \%), 167(50 \%), 124$ (45\%), 109 (25\%), 97 (100\%), 83 (30\%), 69 (325); HRMS (M+) Calc. for $\mathrm{C}_{14} \mathrm{H}_{26} \mathrm{O}_{2} 226.19328$. Found 226.19331.

Synthesis of ( \pm )-6-allyl-6,7-dimethyl-1-oxaspiro[4.5] decan-2-one (10)

To a solution of diol $5(0.03 \mathrm{~g}, 0.133 \mathrm{mmol})$ in a mixture of $\mathrm{CH}_{2} \mathrm{Cl}_{2}: \mathrm{CH}_{3} \mathrm{CN}\left(9: 1,0.33 \mathrm{~cm}^{3}\right)$ were added powder molecular sieves ( $4 \AA, 0.066 \mathrm{~g}$ ), morpholine N-oxide (NMO, $0.0312 \mathrm{~g}$ ) and tetrapropylammonium perruthenate (TPAP, $0.004 \mathrm{~g} 0.011 \mathrm{mmol}$ ). The resulting solution was stirred for $1 \mathrm{~h}$. After that the crude reaction was filtered through a silica gel (230-400 mesh) chromatographic column (eluting with hexane:ehyl acetate 80:20) to furnish $( \pm)-10(0.0235,80 \%)$, as a colorless oil.

IV $\left(v_{\max } / \mathrm{cm}^{-1}\right) 3079,2936,2871,1771(\mathrm{CO}), 1640,1462$, 1218, 1171, 1004, 927 (film); ${ }^{1} \mathrm{H}$ NMR (300 MHz, $\mathrm{CDCl}_{3}$ ): $\delta$ 6.0-5.87 (m, 1H ), 5.02-4.99 (m, 1H), 4.96-4.94 (m, 1H), 2.63-2.43 (m, 2H), 2.39-2.26 (m, 2H), 2.08 (dd, $J 14.8$ and $8.8 \mathrm{~Hz}, 1 \mathrm{H}), 1.96-1.87$ (m, 2H), 1.55-1.19 (m, 6H), 1.06 (s, 3H), $0.93(\mathrm{~d}, J 6.6 \mathrm{~Hz}, 3 \mathrm{H}) ;{ }^{13} \mathrm{C} \mathrm{NMR}\left(75.4 \mathrm{MHz}, \mathrm{CDCl}_{3}\right)$ : $\delta$ 177.0, 136.2, 115.3, 92.0, 43.3, 42.1, 36.9, 33.9, 29.7, 29.0, 28.8, 26.2, 15.8, 14.7; MS (70eV, m/z): 222 (M+, 100\%), 207 (6\%), 151 (20\%), 122 (40\%), 107 (43\%), 69 (26\%); HRMS (M+) Calc. for $\mathrm{C}_{14} \mathrm{H}_{22} \mathrm{O}_{2} 222.16198$. Found 222.16201.

Synthesis of ( \pm )-dehalo-napalilactone (2)

A suspension of the lactone $\mathbf{1 0}(0.012 \mathrm{~g}, 0.054 \mathrm{mmol})$, $\mathrm{PdCl}_{2}(0.001 \mathrm{~g}, 0.005 \mathrm{mmol})$ and $\mathrm{Cu}(\mathrm{OAc})_{2} \cdot \mathrm{H}_{2} \mathrm{O}(0.003 \mathrm{~g}$, $0.010 \mathrm{mmol})$ in $N, N$-dimethylacetamide $\left(0.079 \mathrm{~cm}^{3}\right.$ or $79 \mu \mathrm{L})$ and distilled water $\left(0.013 \mathrm{~cm}^{3}\right.$ or $\left.13 \mu \mathrm{L}\right)$ was stirred at room temperature for 3 days under an $\mathrm{O}_{2}$ atmosphere. After which time $\mathrm{HCl}\left(3 \mathrm{~mol} \mathrm{dm}{ }^{3}\right.$ solution, $\left.0.180 \mathrm{~cm}^{3}\right)$ was added to the solution and the reaction mixture was extracted with ether $\left(5 \times 3 \mathrm{~cm}^{3}\right)$. The organic layer was washed with a saturated solution of $\mathrm{NaHCO}_{3}\left(5 \mathrm{~cm}^{3}\right)$, brine $\left(5 \mathrm{~cm}^{3}\right)$ and dried over $\mathrm{MgSO}_{4}$. The solvent was evaporated under reduced pressure and the oily residue was purified by column chromatography (eluting with hexane:ethyl acetate 80:20) to furnish ( \pm -2 $(0.009 \mathrm{~g}, 60 \%)$, as a crystalline solid.

m.p. 99-101 ${ }^{\circ} \mathrm{C}$; IV $v_{\max } / \mathrm{cm}^{-1} 2924,2924,2871,2859$, 2258, 1771(CO lactone), 1700(CO, methylketone) 1462, 1355, 1224, 1171, 1010, 921, 731 (film); ${ }^{1} \mathrm{H}$ NMR (300 $\left.\mathrm{MHz}, \mathrm{CDCl}_{3}\right): \delta 2.59(\mathrm{~d}, J 13.2 \mathrm{~Hz}, 1 \mathrm{H}), 2.55-2.49(\mathrm{~m}$, 2H), 2.35 (d, J 13.2 Hz, 1H), 2.23 (s, 3H), 2.16-1.98 (m, 1H), 1.93-1.83 (m, 1H), 1.78-1.69 (m, 1H), 1.67-1.59 (m, $2 \mathrm{H}), 1.55-1.38(\mathrm{~m}, 4 \mathrm{H}), 1.30(\mathrm{~s}, 3 \mathrm{H}), 0.88(\mathrm{~d}, J 6.6 \mathrm{~Hz}$, $3 \mathrm{H}) ;{ }^{13} \mathrm{C} \mathrm{NMR}\left(75.4 \mathrm{MHz}, \mathrm{CDCl}_{3}\right): \delta 210.1(\mathrm{CO}), 176.4$ (CO), 91.2, 52.4, 45.5, 37.7, 32.6, 32.1, 29.7, 28.6, 28.5, 25.7, 15.7, 15.6; MS (70eV, m/z); $238(\mathrm{M}+, 15 \%), 220$ (22\%), 192 (3\%), $181(50 \%), 165(7 \%), 151(22 \%), 138$ (5\%), 125 (55\%), 111 (100\%), 85 (70\%), 67 (23\%); HRMS $(\mathrm{M}+)$ Calc for $\mathrm{C}_{14} \mathrm{H}_{22} \mathrm{O}_{3} 238.15689$. Found 238.15689.

\section{Conclusion}

In conclusion, this simple and direct strategy has 
permitted us to describe the first racemic total synthesis of dehalo-napalilactone (2), a non-natural sesquiterpene. Dehalo-napalilactone (2) was prepared in 6 steps from methylcyclohexenone with an overall yield of $16 \%$. Additional modifications to this strategy are ongoing in our laboratory, our objective being the total synthesis of $( \pm)$-napalilactone (1) and ( \pm )-pathylactone (3).

\section{Acknowledgments}

The authors thank CNPq for a grant to GDM and FAPESP (1996/04293-2) for financial support.

\section{References}

1. For a remarkable example of substances isolated from natural sources and their total syntheses, see: Nicolaou, K.C.; Vourloumis, D.; Winssinger, N.; Baran, P.S. Angew. Chem., Int. Ed. Eng. 2000, 39, 45.

2. (a) Scheuer, P.J. Med. Res. Rev. 1989, 68, 1699; (b) Pietra, F. Nat. Prod. Rep. 1997, 14, 453; (c) Fujiki, H.; Suganuma, M.; Yatsunami, J.; Komori, A.; Okabe, S.; Nishiwakimatsushima, R.; Ohta, T. Gazz. Chim. Ital. 1993, 123, 309; (d) Scheuer, P.J.; J. Nat. Toxins 1996, 5, 181.

3. (a) Albizati, K.F., Martin, V.A., Agharahimi, M.R. and Stolze, D.A., In Bioorganic Marine Chemistry, P.J. Scheuer, Ed. Springer-Verlag, Berlin, 1992, vol 5; (b) Albizati, K.F., Martin, V.A., Agharahimi, M.R. and Stolze, D.A. In Bioorganic Marine Chemistry, edited by P.J. Scheuer, Springer-Verlag, Berlin, 1992, vol 6; (c) Nicolaou, K.C.; Sorensen, E.J.; Winssinger, N. J. Chem. Educ. 1998, 75, 1225.

4. Carney, J.R.; Pham, A. T.; Yoshida, W.Y.; Scheuer, P.J. Tetrahedron Lett. 1992, 33, 7115.

5. Su, J-Y.; Zhong, Y.-L.; Zeng, L.-M. J. Nat. Prod. 1993, 56 ,

6. (a) Hua, D.H.; Chen, Y.; Sin, H.S.; Maroto, M.J.; Robinson, P.D.; Newell, S.W.; Perchellet, E.M.; Ladesich, J.B.; Freeman, J.A.; Perchellet, J.P.: Chang, P.K. J. Org. Chem. 1997, 62, 6888; (b) Nwaukwa, S.O.; Keehn, P.M. Tetrahedron Lett. 1982, 23, 35.

7. Boeckman Jr. R.K. J. Org. Chem. 1973, 38, 4450.

8. Duhamel, P.; Dujardin, G.; Hennequin, L.; Poirier, J. -M. J. Chem. Soc., Perkin Trans. 1 1992, 387.

9. Johnson F. Chem. Rev. 1968, 68, 375.

10. Haraldsson, G.G.; Paquette, L.A.; Springer, J.P. J. Chem. Soc., Chem. Commun. 1985, 1025.

11. Srikrishna, A.; Reddy, T.J.; Nagaraju, S.; Sattigeri, J.A. Tetrahedron Lett. 1994, 35, 7841.

12. Urbanek, R.A.; Sabes, S.F.; Forsyth, C.J. J. Am. Chem. Soc. 1998, 120, 2523.

13. Chen, C.-Y.; Reamer, R.A. Org. Lett. 1999, 1, 292.

14. Mehta, G.; Karra, S.R. Tetrahedron Lett. 1991, 32, 3215.

15. Smith, A.B.; Cho, Y.S.; Friestad, G.K. Tetrahedron Lett. 1998, 39, 8765.

16. Posner, G.H. Org. React. 1972, 9, 1.

Received: November 14, 2000

Published on the web: May 16, 2001

FAPESP helped in meeting the publication costs of this article. 